\title{
Application of Heuristic Teaching Method in Mould Design Course
}

\author{
Dunbo Teng \\ Yantai Nanshan University \\ Longkou, Shandong, China 265713
}

\begin{abstract}
Start from the characteristics of content and requirements of mould design course; emphasize seriously doing a good job in education of learning goals and make efforts to stimulate students' active thinking, cultivate students' ability to apply knowledge, consciously apply elicitation method of teaching principle to continuously improve teaching efficiency. In the process of teaching, simultaneously using many teaching methods can get the ideal teaching result. It is well known that in various kinds of teaching methods, heuristic teaching method plays a leading role.
\end{abstract}

Keywords-define the goal; actively guide; stimulate thinking; improve ability

\section{INTRODUCTION}

It is the task discussed by many teachers together about how to teach the mould design course well. In order to obtain good teaching effects, in reality, they consciously or unconsciously follow the correct elicitation method of teaching principle; otherwise, the teaching effect will be influenced. The content of mould course has strong practicality and covers a wide range. In teaching process, there exist phenomena that students' learning is passive and it is difficult to arouse their enthusiasm. Therefore, the teaching team reforms traditional teaching method, adopts a variety of teaching methods for different teaching contents. For example, use heuristic teaching method to stimulate students' learning interest, the teaching method of "classroom factorization" to strengthen students" practical ability, task-driven teaching method to improve students' ability in analyzing and solving problems, and then get good teaching effect. Start from heuristic teaching method, base on characteristics of students in higher vocational colleges and apply heuristic teaching method in mould design teaching. Mastering teaching techniques can fully arouse students' enthusiasm in learning, initiative and creativity and guide students to cultivate the ability in analyzing and solving problems through their independent thinking and strengthen operational ability and innovation ability. It is the teaching practice between teaching practice and scientific research, can furthest arouse students' subjective initiative and enthusiasm, fully respect students' intelligence and individuality, help to cultivate innovative talents and truly embody people-oriented educational thought. The original "spoon-feeding" teaching model cannot adapt to requirements of design practice. It is necessary to explore new teaching model of course deign practice to improve experiment effect. Heuristic teaching method is one of them.
Heuristic teaching method means that teachers base on teaching objectives, start from students' practical knowledge base, ideological level and learning level, adopt various teaching inspiration means, fully arouse students' enthusiasm in learning and exert their main body role in learning as well as make them actively acquire knowledge and develop intelligence through active thinking, operation and exercise. Moulds designed in mould course are diversified. The same part can be made by using different stamping schemes, but the efficiency is different. In a short period, it is difficult for beginners to have the ability to skillfully calculate and design moulds through learning this course. In teaching, except for letting students grasp the steps of mould design and drawing methods, it is more important to continuously cultivate students' imagination power of spatial thinking. The cultivation of this ability cannot rely on teachers to repeatedly emphasize the concept and force on students. It cannot adopt the method that teachers carry out cramming education, replace thinking with teaching and students take examinations by memorizing mechanically. The effective method is: it can be obtained through teachers' systematic and comprehensive teaching guidance and students' repeated independent thinking and continuous practice. In teaching, teachers shall adopt a variety of teaching forms, furthest stimulate students' initiative and enthusiasm, arouse students' active thinking, make students acquire knowledge through digestion, which are also the essence contents of elicitation method of teaching principle. Therefore, in teaching, in order to do well in education of learning goals, it is necessary to use elicitation method of teaching principle to guide teaching jobs.

\section{IMPLEMENT EDUCATION OF LEARNING GOALS ON STUDENTS}

It mainly means letting students have enough psychological preparation and psychological demand before accepting this course and producing the learning motivation that never give up to reach the goal, namely "go deep into the mountain, knowing well that there are tigers there", to actively overcome difficulties in learning. How to carry out education of learning goals? People often say, "Well begun is half done". Firstly, teachers shall teach the introduction class well, because the introduction class comprehensively introduces contents of this course, what's more, it is to trigger students' interest in learning and mobilize their learning initiative. Therefore, in introduction class, teachers shall avoid empty talk. They should explain profound theories in living examples, vividly 
and interestingly tell the functions of parts in production, and make students clearly knowledge learning goals, meanwhile, lay good foundation for cultivating students' serious and responsible attitude in drawing and meticulous work style.

The education of learning goal cannot be carried out in one time. It is necessary to carry out the education of learning goals before each chapter or each section. For example, in teaching the chapter of "stock layout of punching parts", firstly, teachers shall draw to analyze different layout plans and the use ratio of materials to make students understand that the stock layout is not to make it pleasing to the eye. It is more important to seriously base on principle of stock layout to design layout drawing well because of requirements for use ratio of materials. When teachers teach contents of the section of "blanking force and press machine", students always feel boring and think those are only some formula and table lookup, nothing for them to learn. They lack serious attitudes and easily make mistakes in application. At this time, if teachers want to guide from the perspective of learning goals and let students realize that formula and table look-up data shall become language to communicate, they shall follow relevant standards and stipulations to strengthen students' learning emotion, improve learning effects and seriously master relevant provisions to consciously follow in the process of looking up the table. Teachers can actively exert students' dynamic role in learning and stimulate students' active thinking only through letting students clearly understand why they have to learn. Therefore, the teaching cannot ignore the education of learning goals, but seize the opportunity to implement the education of learning goals on students.

It is of great difficulty in learning the course and the contents are boring. Aiming at problems produced in traditional "spoon-feeding", carry out group discussion to further explain and analyze relevant theories. Ordinary infuseteaching method has many deficiencies in teaching this course, makes it difficult for students to perceive and understand the knowledge of mould design course and learn professional knowledge contents. Meanwhile, it cannot stimulate students' learning emotion. There exists big difference between professional knowledge taught in class and actual engineering practice. Teachers shall exercise students' thinking ability and make them form rational knowledge on knowledge that they learn in class. Therefore, in teaching process, teachers shall adopt flexible and diversified teaching forms and try every means to stimulate students' active thinking and guide students to learn actively.

\section{ClassRoOM QUESTIONING}

The ancients say, "It is necessary to raise questions in learning". Questions are the starting point to learn knowledge. If there is question, there is query and study. Having questions means the initiative and enthusiasm of learning. Classroom questioning is an effective method to guide students to think. So it contains many artistic qualities of teaching about how to ask questions to mobilize students' enthusiasm, simplify a complicated problem for students to think. It needs teachers to have deep consideration in the process of preparing lessons, flexibly dispose in teaching and handle classroom teaching contents through adapting themselves to changing circumstances according to students' concrete reflection to achieve good teaching effects.

For example, when teaching the section of "use ratio of materials in blanking", no matter how big the hole of the workpiece is or no matter how is the shape, first of all, it is necessary to know that the holes on workpiece belong to structural waste material. Therefore, when teachers teach the use rate of materials, they shall ask questions about "structural waste material and process waste material", let students answer after thinking. On this basis, the problems about drawing will be easy. Otherwise, if the teacher only teach the method, it makes students know the surface phenomenon but don't know the nature and reason, let alone the understanding of knowledge.

When teachers teach "assembly drawing of moulds", in face of assembly drawing of mould formed by dozens of parts, students will be at a loss. How to make students understand? Instead of carefully teaching the contents on drawing from beginning to end to let students accept passively, it's better to simply summarize working principle of mould shown in the drawing, and then raise some questions according to movement route and assembly relationship in the drawing, inspire students to think and analyze, guide them to understand the functions according to structure of parts and understand the design idea of designers according to the functions and take the methods of deeper investigation and increasingly in-depth research. It not only lets students' learning change from passive acceptance to active thinking, but also cultivates students' ability to analyze and solve problems.

\section{ORGANIZE ClassRoOM Discussions ACCORDING TO PROBLEMS}

It is one of the effective methods to stimulate thinking of students, promote exchange of ideas, deepen understanding, correct mistakes, avoid mechanical memorization and improve teaching effects.

For example, when teachers teach "design of bending die", if they give the definition directly, students always use the method of comparison to memorize. They will understand the bending in length as the length when the panel veneer is flat. If the teacher puts forward the definition that the stress on outer layer is different from the stress on inner layer at first, take the form of classroom discussions, let students express their opinions to correct wrong and unclear understanding of each other in the discussion, students will establish right concept. For another example, in the teaching of "choice of total design scheme of mould", students want to find a perfect scheme to express a mould, but they will always be at a loss finally. At that time, if teachers can choose questions according to expressing scheme of concrete parts, organize students to discuss in class, guide students to exchange ideas, list expressing scheme that they can think and compare advantages and disadvantages to get the optimal decision, it can not only make students timely understand the application of knowledge in learning process, but also avoid the occurrence of the above problems. In addition, the classroom will form the scene with heated discussion, immense interest and active thinking. 


\section{FleXIBly Organize Classroom TEACHING CONTENTS}

It is another measure to stimulate students' active thinking. The arrangement of textbook contents often follows the evolutionary principle from the shallower to the deeper. In order to stimulate the thinking of students, sometimes teachers shall avoid repeating what the book says, and adjust the contents flexibly and properly, make students experience the feeling that they will "pick peaches" by making some efforts in learning process.

For example, in explaining "mould of plastics", teachers shall firstly discuss materials and structure technology of plastic parts, and then discuss injection molding and gating system. Students' contact scope and scope of knowledge gradually expand. Teaching these contents according to this order can help students understand manufacturing process of plastic parts step by step. Therefore, in teaching these contents, firstly, teachers shall give a simple plastic parts to let students think and feel how to make to attract their attention, and then analyze the problems that the students don't understand to introduce the concept and explain in detail. In this way, teachers can greatly arouse students' interest in learning as well as improve their learning efficiency.

The above mentioned are the most frequently-used methods to stimulate students' thinking in teaching. Besides, teachers can organize some exercise classes and remedial lessons, help students to make some models or use teaching aids to stimulate thinking of students in learning.

In order to effectively stimulate thinking of students, teachers must thoroughly get familiar with and study teaching materials, accurately grasp the key points, difficulties and doubtful points of teaching materials, know well about knowledge base, receptivity, learning interest and hobbies of students, existing difficulties and doubtful points, always regard students as principal part of teaching, cultivate students' ability to apply knowledge, have a definite object in view and make the best use of the circumstances. Only in this way can teachers truly and correctly enlighten students.

The application of knowledge is on the basis of acquiring knowledge. The nature of it is also a leap of knowledge and expression of subjective initiative of learning. So in teaching, teachers shall pay attention to students' ability in applying knowledge and urge students to learn actively.

For example, in teaching "calculating cutting edge of blanking die", teachers can let students discuss reasonable clearance value of mould, guide students to use the difference value method that they have learnt to solve the problem, and make them further understand inner links of knowledge, deepen the understanding for knowledge and creatively study and apply in learning process.

Mould course has strong practicality. After teaching some contents, teachers must timely arrange a certain amount of exercises, make students consolidate knowledge through designing calculation, as well as use many practical forms such as simulation and surveying and mapping to let students apply what they have learnt.

\section{CONCLUSION}

To sum up, in order to learn mould course well, it is necessary to furthest mobilize students' active thinking and the initiative to learn actively as well as cultivate their ability in flexibly applying their knowledge. The problem solved by elicitation method of teaching principle is about how to organically integrate teachers' teaching with students' enthusiasm of learning in teaching and deal with relationships between learning and thinking as well as thinking and application. Therefore, in teaching of drawing, it is essential to pay special attention to flexible application of elicitation method of teaching principle.

\section{REFERENCES}

[1] Li Guodong. Research on Positioning of Training Objectives of Higher Vocational Education [M], Jiangsu Education Publishing House, 2005, 3

[2] Huang Hong. Plastic Molding and Processing and Mould [M], Beijing: Chemical Industry Press, 2003

[3] Huang Rui. Plastic Engineering Manual [M], Beijing: China Machine Press, 2012

[4] Song Zhuoyi, Shi Qinfang. Plastic Raw Materials and Auxiliaries [M], Beijing: Science and Technology Literature Press, 2003

[5] Huang Rui. Plastic Molding Technology [M], Beijing: China Light Industry Press, 1997

[6] Liu Caiying. Plastic Pattern Design Manual [M] (software version), Beijing: China Machine Press, 2010

[7] Wang Wenguang. Design Tactics and Living Examples of Plastic Injection Mold [M], Beijing: Chemical Industry Press, 2004

[8] Tian Chunnian. Structure Design Manual of Plastic Injection Mold [M], Beijing: Light Industry Press, 1998

[9] Cao Hongshen, Zhao Zhongzhi. Plastic Molding Process and Mold Design [M], Beijing: Beijing Mechanical Industry Publishing House, 1993 